\title{
The Effect of Perceived Risk in Online Shopping in Jordan: The Mediating Role of Intention and the Moderating Role of Experience
}

\author{
Muath Ayman Tarawneh, Abdul Malek Bin A. Tambi, Mutia Sobihah
}

To Link this Article: http://dx.doi.org/10.6007/IJARBSS/v11-i3/8490

DOI:10.6007/IJARBSS/v11-i3/8490

Received: 21 January 2021, Revised: 23 February 2021, Accepted: 03 March 2021

Published Online: 16 March 2021

In-Text Citation: (Tarawneh et al., 2021)

To Cite this Article: Tarawneh, M. A., Tambi, A. M. B. A., \& Sobihah, M. (2021). The Effect of Perceived Risk in Online Shopping in Jordan: The Mediating Role of Intention and the Moderating Role of Experience. International Journal of Academic Research in Business and Social Sciences, 11(3), 406-421.

\section{Copyright: @ 2021 The Author(s)}

Published by Human Resource Management Academic Research Society (www.hrmars.com)

This article is published under the Creative Commons Attribution (CC BY 4.0) license. Anyone may reproduce, distribute, translate and create derivative works of this article (for both commercial and non-commercial purposes), subject to full attribution to the original publication and authors. The full terms of this license may be seen at: http://creativecommons.org/licences/by/4.0/legalcode

\section{Vol. 11, No. 3, 2021, Pg. 406 - 421}




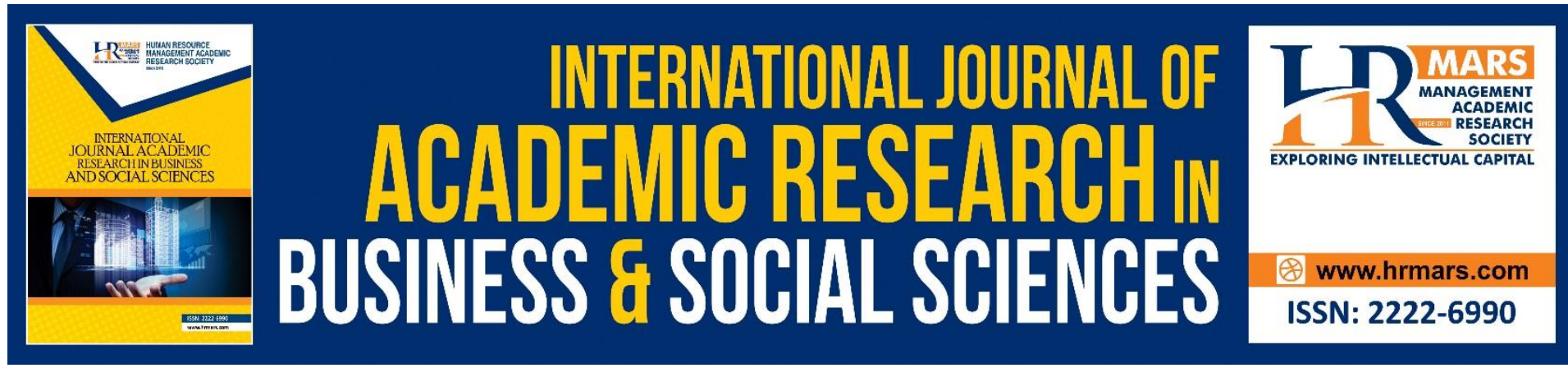

\title{
The Effect of Perceived Risk in Online Shopping in Jordan: The Mediating Role of Intention and the Moderating Role of Experience
}

\author{
Muath Ayman Tarawneh, Prof. Abdul Malek Bin A. Tambi, \\ Assoc. Prof. Dr. Mutia Sobihah \\ Faculty of business and management, Universiti Sultan Zainal Abidin (UniSZA), 21300 Kuala \\ Terengganu, Malaysia \\ Email: tarawneh.moad@gmail.com
}

\begin{abstract}
The aim of this paper is to investigate perceived risk as a second-order construct with three dimensions, namely: financial and performance and time risks in the context of Jordan and its effect on online shopping behavior. Moreover, to investigate the role of experience as a moderator on the relationship between perceived risk and actual online shopping behavior. Finally, to investigate the mediation effect of intention between perceived risk and actual online shopping behavior. Theory of planned behavior was adopted in this study. The research was conducted based on empirical data collected through an emailed questionnaire from university students in Jordan. IBM SPSS AMOS version 24.0 was utilized for data analysis. The findings indicated that intention partially mediated the relationship between perceived risk and actual online shopping behavior. Further, the experience was moderate the relationship between perceived risk and actual online shopping behavior.
\end{abstract}

Keywords: Perceived Risk, Intention, Actual Online Shopping Behavior, Theory of Planned Behavior (TPB), Online Shopping

\section{Introduction}

\section{Background of the Study}

The internet is a common, community-oriented and self-sufficient setup that can be utilized by a vast number of individuals around the globe (THAM et al., 2019). The headway of internet innovation has made the development of online shopping beyond legacy methods and has become an inherent piece of life in the 21st century. The internet permits purchasers to shop whenever, anyplace, with the capacity to compare items and costs with a few clicks and to have a look at the reviews of other buyers for the desired product.

In the context of Jordan, despite of the internet penetration is quite high (88\%), the Department of Statistics in Jordan (2017) determined that online shopping is low as $4.8 \%$ only (Alsoud \& Othman, 2018).

Due to the absence of face-to-face contacts in the online shopping market, examining and recognizing factors that impact the shopper is crucial. Customers have different characters and purposes when they are attempting to purchase online. Some are searching for items or 
services, making study or looking at cost. A portion of the potential purchasers will continue with online buy. Else, they are simply doing a survey, comparing price and availability information, but not continuing to buy. To improve internet shopping, understanding online behavior and intention towards online shopping should be prioritized (Wen et al., 2020).

With the growth of online shopping, consumers have to deal with risks about the product, the environment, or the buying process. Literature has reported that perceived risk is a fundamental factor in determining the acceptance rate of online shopping (Orubu, 2016). In marketing literature, it was reported that perceived risk directly affects purchasing and purchase intention, i.e., when consumers have high perceived risk, the probability of consumers shopping online will be low (Ariff et al., 2014).

Moreover, other factors such as online shopping experience are vital in online shopping, but despite its core importance, online shopping experience research is still limited and fragmented (Kawaf \& Tagg, 2017). Hence, this study investigates the moderating role of experience on the relationship between perceived risk and actual online shopping behavior. Further, the mediating effect of intention between perceived risk and actual online shopping behavior.

\section{Objective of the Study}

1- To investigate the effect of perceived risk on intention.

2- To investigate the effect of perceived risk on actual online shopping behavior.

3- To investigate the effect of intention on actual online shopping behavior.

4- To investigate the mediating effect of intention between perceived risk and actual online shopping behavior.

5- To investigate the moderating effect of experience on the relationship between perceived risk and actual online shopping behavior.

\section{Significance of the Study}

This study aims to understand consumers' behavior in online shopping in the context of Jordan by utilizing the theory of planned behavior to investigate the influence of perceived risk and online shopping experience in online shopping. Hence, this would enhance a better understanding of online retailers about the effect of these factors on consumers' decisions to shop online, which will contribute to developing online shopping for the future.

\section{Literature Review and Hypothesis Development Online Shopping}

According to (Rizwan et al., 2014), online shopping is a process where the customer buys products and services directly from the internet as a medium. Online shopping is an ecommerce transaction where the consumers make the purchase in the platform and interact directly with the seller. E-commerce is also known as e-shopping, online shopping and internet shopping (Vaux, 2011).

\section{Relationship Between Perceived Risk, Intention and Actual Online Shopping Behavior}

According to (Schierz et al., 2010), Perceived risk is the losses expectation. Greater expectations of losses mean higher level of risk. perceived risk is a negative insight that produce based on the unpredicted and changeable results that can be perceived from the purchased products (Laroche et al., 2005). Whereas, Ko et al. (2004) stated that perceived 
risk is related to consumers' perception regarding adjustable and contrary results of purchasing a product or a service.

(Ahmed \& Akhlaq, 2015) indicated in their study that perceived risk was found to have a negative impact on consumer's intentions to buy online, which proposes that customers' intention to buy online will be reduced whenever they understand that the transaction is risky. In other words, customers will not be engaged in online purchasing once they notice that the level of risk is high. In literature, it was proved that perceived risk has a negative effect on online shopping intention, (Zhao et al., 2017; Ahmed \& Akhlaq, 2015). Moreover, (Zhang et al., 2012) reported in his study that perceived risk has a statistically significant but negative impact on online shopping behavior.

According to online shopping literature, there is (up 'til now) no concurred set of dimensions for perceived risk (Al-Rawad et al., 2015). In this research, the perceived risk is considered a second-order construct with two dimensions: financial risk and performance risk.

Two dimensions of perceived risk were found to be fundamental, First, financial risk, which was defined as the monetary loss that can potentially occur from initial purchase of a product and its following maintenance (Featherman \& Pavlou, 2003). Second, performance risk was defined as the likelihood that a product may fail to meet the performance that originally was intended for (Zheng et al., 2012). Finally, time risk is described as "the amount of time taken for the product to be received and time \& effort wasted in returning or exchanging the product (Hassan et al., 2006).

\section{Relationship Between the Effect of Intention on Actual Online Shopping Behavior}

According to Ajzen (1991), intentions are assumed to be the indicator to understand the extend of people willingness to perform a certain behavior and how many attempts, they are willing to try to perform a specific behavior. The intention has been determined as a salient predictor of actual online shopping behavior (Lim et al., 2016).

Jamil (2012), in his study to investigate the determinant of online purchasing behavior in Malaysia relying on integrating two theories, Theory of Planned Behavior (TPB) and Technology Acceptance Model (TAM). Results proved that there is a statistically significant and positive impact of intentions on actual online shopping behavior. Moreover, according to (Al-Jabari, 2013), who conducted a study among 317 academic staff in Jordan from ten universities, his results revealed that intention significantly affects actual online shopping behavior.

\section{Moderating Effect of Experience on the Relationship Between Perceived Risk and Actual Online Shopping Behavior}

There are several terms that come with customer experience, and these include online shopping experience (Chen et al., 2009), online customer experience (Liao \& Keng, 2013), and web experience (Constantinides et al., 2013).

Chen et al. (2009) considered the online shopping experience as the frequency of online purchases. Moreover, it can also be related to the number of purchases that the consumer has previously made (Pappas et al., 2014).

Customers have amassed more online experience over the previous decade, and thus accordingly may hold diverse all-encompassing perspectives of online shopping, together with risk perceptions. Investigating how online shopping experience affects risk perceptions in the field of online shopping does not stop in expanding the consideration of the importance of risk perceptions and its effect on online shopping, but it goes beyond to gives meaningful 
implications for marketers to develop complementary strategies to counter the effect of risk perceptions that are adversely associated with online shopping (Dai et al., 2014).

Accordingly, the following hypothesis were developed:

$\mathrm{H} 1$ : There is a negative relationship between perceived risk and intention.

$\mathrm{H} 2$ : There is a negative relationship between perceived risk and actual online shopping behavior.

H3: There is a positive relationship between intention and actual online shopping behavior.

H4: Intention mediates the relationship between perceived risk and actual online shopping behavior.

H5: Experience moderates the relationship between perceived risk and actual online shopping behavior.

\section{Research Methodology}

\section{Theoretical Framework}

The main theory considered to be suitable for the current study is Theory of Planned Behavior(TPB), because it can predict human behavior and explain customer's decisionmaking process toward a particular product (Ajzen, 1991).

The proposed model of this research showed in figure 1 below.

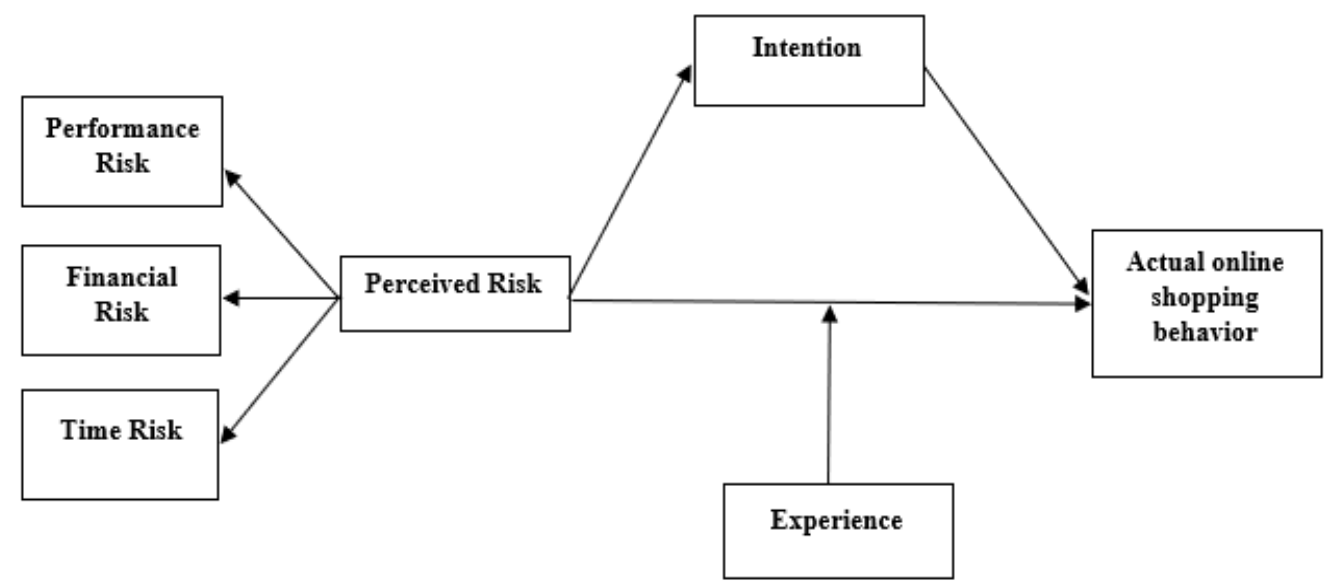

\section{Analysis And Findings \\ Confirmatory Factor Analysis (Cfa)}

Figure 1: A proposed model

CFA was performed using the software IBM-SPSS AMOS 24 for the purpose of confirming the factor structure, dropping items with low factor loadings, and to evaluate the constructs convergent validity. latent constructs are considered valid if it achieved the required value of fitness indexes. Specifically, three Model Fit categories should be achieved; Absolute Fit index, Incremental Fit index and Parsimonious Fit index (Awang et al., 2015, 2018; Kashif et al., 2015; 2016; Noor et al., 2015; Yusof et al., 2018). Table 1 illustrates the fitness indexes and their acceptable range values. 
Table 1: acceptable range values for the categories of model fit

\begin{tabular}{|l|l|l|}
\hline Name of category & $\begin{array}{l}\text { Name of } \\
\text { index }\end{array}$ & $\begin{array}{l}\text { Level of } \\
\text { acceptance }\end{array}$ \\
\hline Absolute Fit Index & $\mathrm{RMSEA}$ & $\mathrm{RMSEA}<0.08$ \\
\cline { 2 - 3 } & $\mathrm{GFI}$ & $\mathrm{GFI}>0.90$ \\
\hline \multirow{2}{*}{$\begin{array}{l}\text { Incremental Fit } \\
\text { Index }\end{array}$} & $\mathrm{AGFI}$ & $\mathrm{AGFI}>0.90$ \\
\cline { 2 - 3 } & $\mathrm{CFI}$ & $\mathrm{CFI}>0.90$ \\
\cline { 2 - 3 } & $\mathrm{TLI}$ & $\mathrm{TLI}>0.90$ \\
\cline { 2 - 3 } & $\mathrm{NFI}$ & $\mathrm{NFI}>0.90$ \\
\hline \multirow{2}{*}{$\begin{array}{l}\text { Parsimonious Fit } \\
\text { Index }\end{array}$} & $\mathrm{Chisq} / \mathrm{df}$ & $\begin{array}{l}\mathrm{Chi}-\text { Square/ df }< \\
5.0\end{array}$ \\
\hline
\end{tabular}

Source: Awang et al. (2018)

This study's framework consists of one exogenous construct, one mediator construct, one moderator construct, and one endogenous construct.

\section{The Pooled Confirmatory Factor Analysis (CFA)}

The Pooled-CFA procedure was carried out for validating all constructs in the model at once since the model is not too complicated. The result of the Pooled-CFA procedure is shown in figure 2.

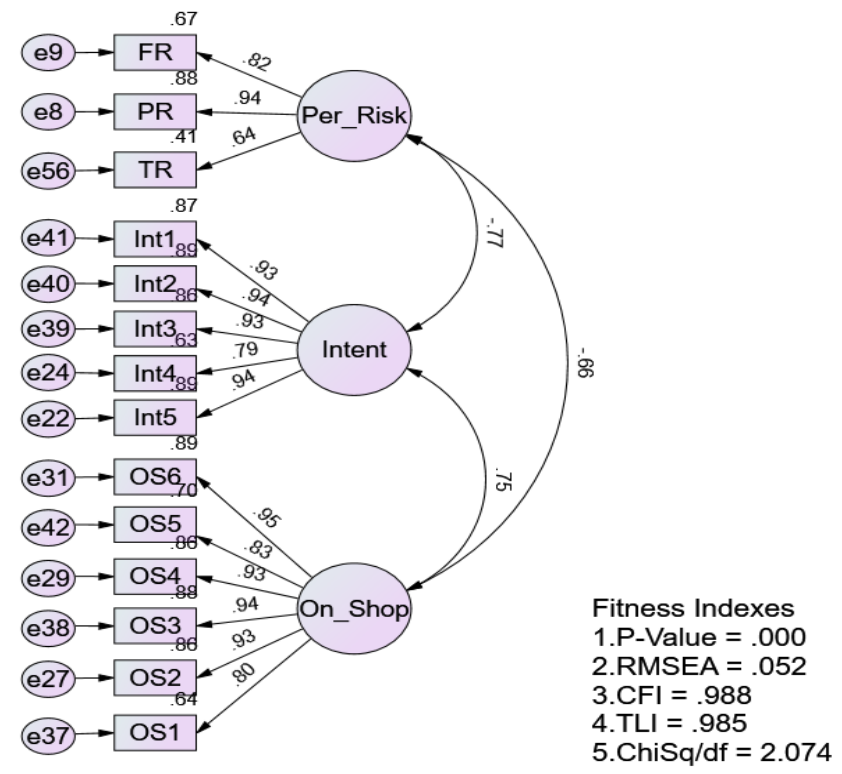

Figure 2: The Pooled CFA presents the factor loading for every item as well as components

\section{The Validating Procedure for the Construct}

As shown in figure 2, all constructs fitness indexes, the factor loading for every component, and the factor loading of each item are shown. Therefore, the researcher was able to assess the Construct Validity, Convergent Validity, Discriminant Validity and Composite Reliability for the construct.

For instance, the Perceived risk construct has two components, namely, financial risk and performance risk. The factor loading for financial risk is 0.74 , while the factor loading for performance risk is 0.97 . Both factor loadings were found in a good range since they exceeded the threshold value of 0.6 (Awang, 2015; Awang et al., 2018). 


\section{The Assessment of Construct Validity for all Constructs}

Based on the results in figure 2, The fitness Indexes found in the accepted range, as indicated in table 1 . The Absolute Fit category, namely RMSEA is 0.052 , the Incremental Fit category, namely CFI is 0.986 , and finally, the Parsimonious Fit category, namely the ratio of Chisq/df is 2.097. Thus, the measurement model of perceived risk, intention, experience and actual online shopping behavior constructs have fulfilled the criteria for Construct Validity (Awang, 2012; 2015; Awang et al., 2015, 2018; Kashif et al., 2015, 2016; Noor et al., 2015; and Afthanorhan et al., 2017, 2017a, 2018, 2019).

\section{Structural Equation Modeling (SEM)}

After the CFA report has been completed and all values have fulfilled the required validity and reliability thresholds, the author will conclude that the measurement models have been validated for all latent constructs involved in the model. (Awang, 2015; Awang et al., 2018; Mohamad et al., 2016, 2017, 2018; Yusuf et al., 2017; Afthanorhan et al., 2017, 2017a, 2018, 2019).

The next step is the assembly of these constructs into the structural model to perform Structural Equation Modeling (SEM). Constructs should be placed from left to right. The exogenous constructs should be placed on the far left. In the middle, the mediator constructs and the endogenous constructs at the far right (Awang, 2015; Mohamad et al., 2016, 2016a; Yusuf et al., 2017). The researcher then using the single-headed arrow connects the exogenous construct with its related endogenous construct, according to the hypothesis direction. Lastly, using the double-headed arrow, as presented in figure 3, all exogenous constructs are related.

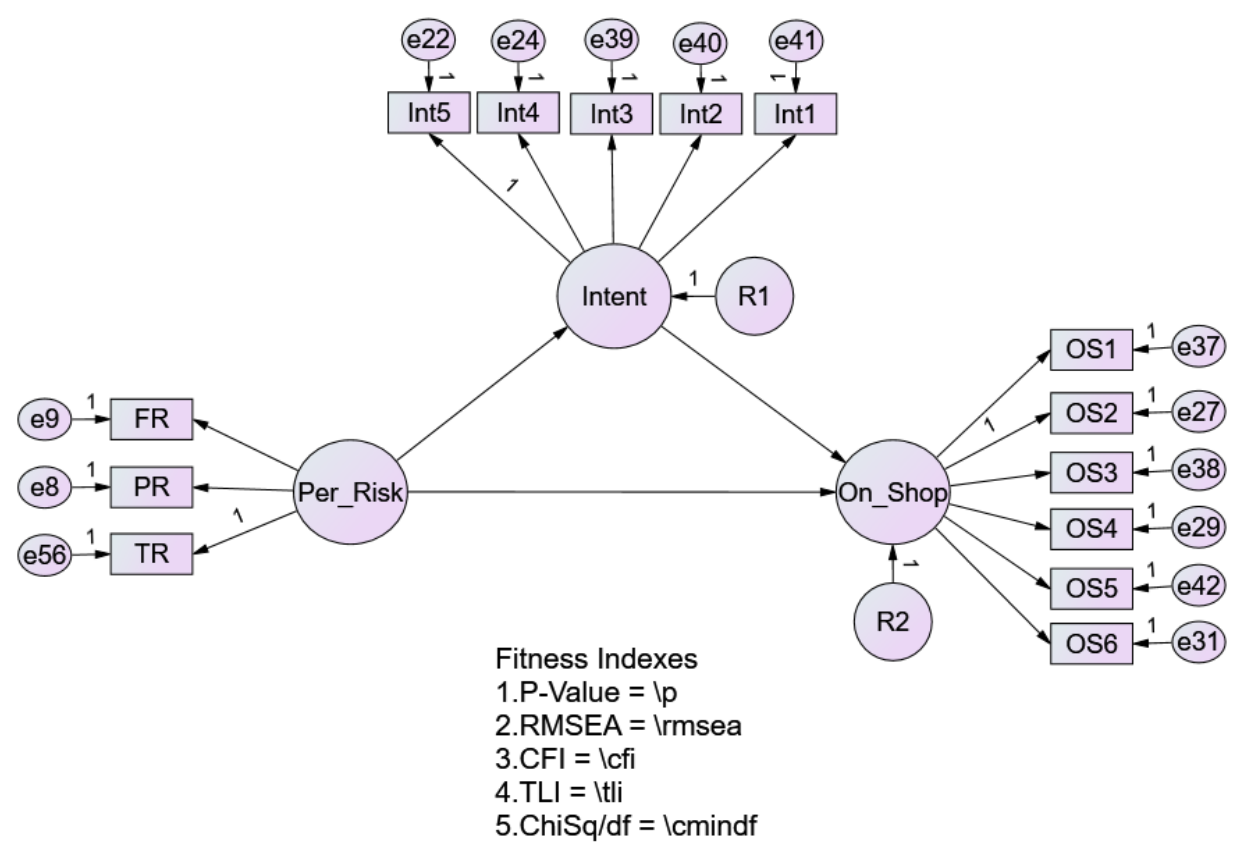

Figure 3: The Structural Model ready to execute SEM

The single-headed arrow (Figure 3) demonstrates the causal effects being estimated of an exogenous construct on the related endogenous construct. Based on predetermined hypotheses, all single-headed arrows are drawn to be tested. If there is more than one exogenous construct in the structural model, then a double-headed arrow can be used between all exogenous constructs to estimate the correlational effects. To prevent the 
multicollinearity problem in the model where there is a high correlation between two exogenous constructs, the study must assess the strength of the link between the exogenous constructs. If there is a correlation between a pair of exogenous constructs above 0.85 , it indicates that constructs are highly correlated, which means the existence of multicollinearity problem (Kashif et al., 2015, 2016, 2017; Noor et al., 2015; Yusof et al., 2017; Aziz et al., 2016; Mohamad et al., 2016, 2017, 2018).

The results of performing SEM is presented in figure 3 for the Standardized Regression Path Coefficients between constructs, and figure 4 for the Regression Path Coefficients between constructs.

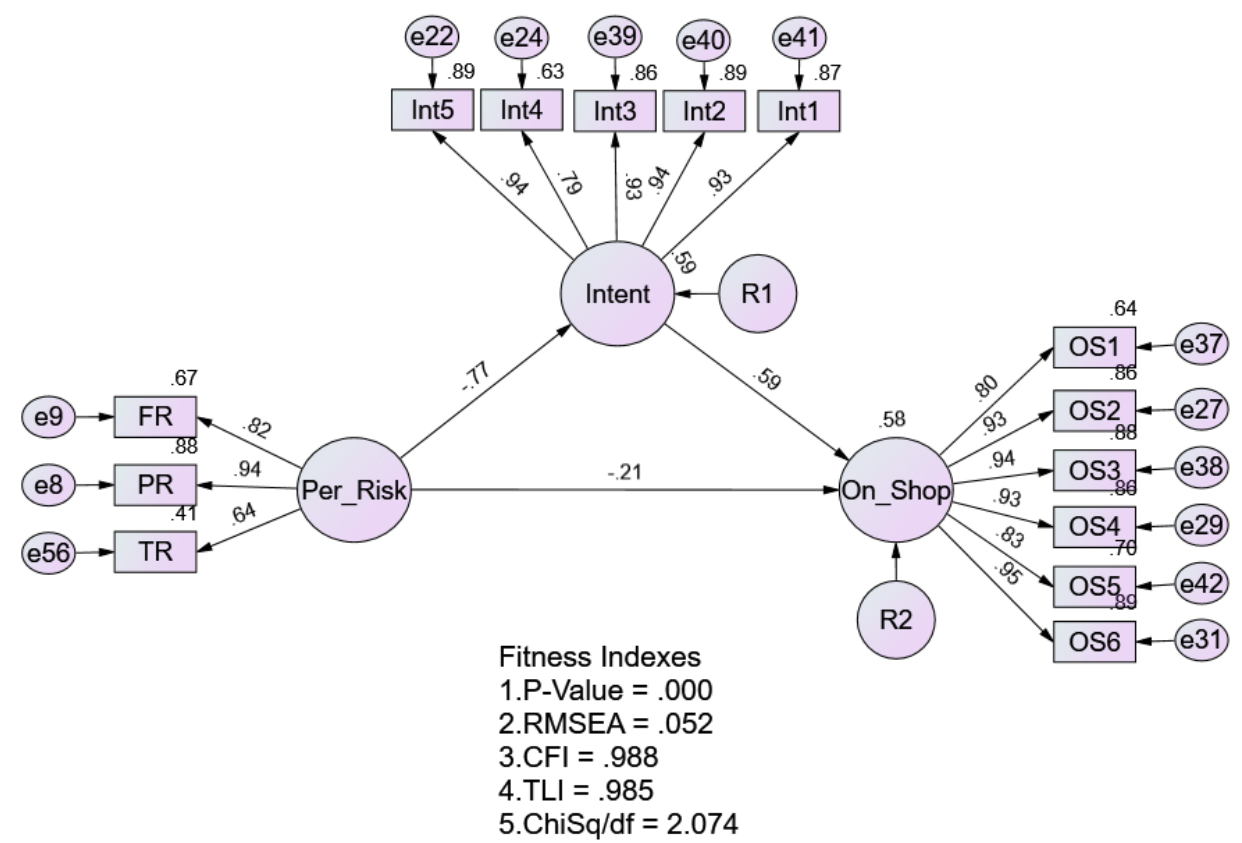

Figure 3: The Standardized Regression Path Coefficient between constructs in the model. The interpretation of R2 for the model (figure 3) is presented in Table 2.

Table 2: The interpretation of R2

\begin{tabular}{|l|l|l|}
\hline Endogenous Construct & $\mathbf{R 2}$ & Conclusion \\
\hline Intention & 0.59 & $\begin{array}{l}\text { The perceived risk construct manages to explain } \\
\text { about 0.59 percent of intention. }\end{array}$ \\
\hline $\begin{array}{l}\text { Actual online shopping } \\
\text { behavior }\end{array}$ & 0.58 & $\begin{array}{l}\text { The perceived risk and intention constructs manage } \\
\text { to explain about 0.58 percent of actual online } \\
\text { shopping behavior. }\end{array}$ \\
\hline
\end{tabular}


For all constructs, figure 4 shows the regression path coefficients.

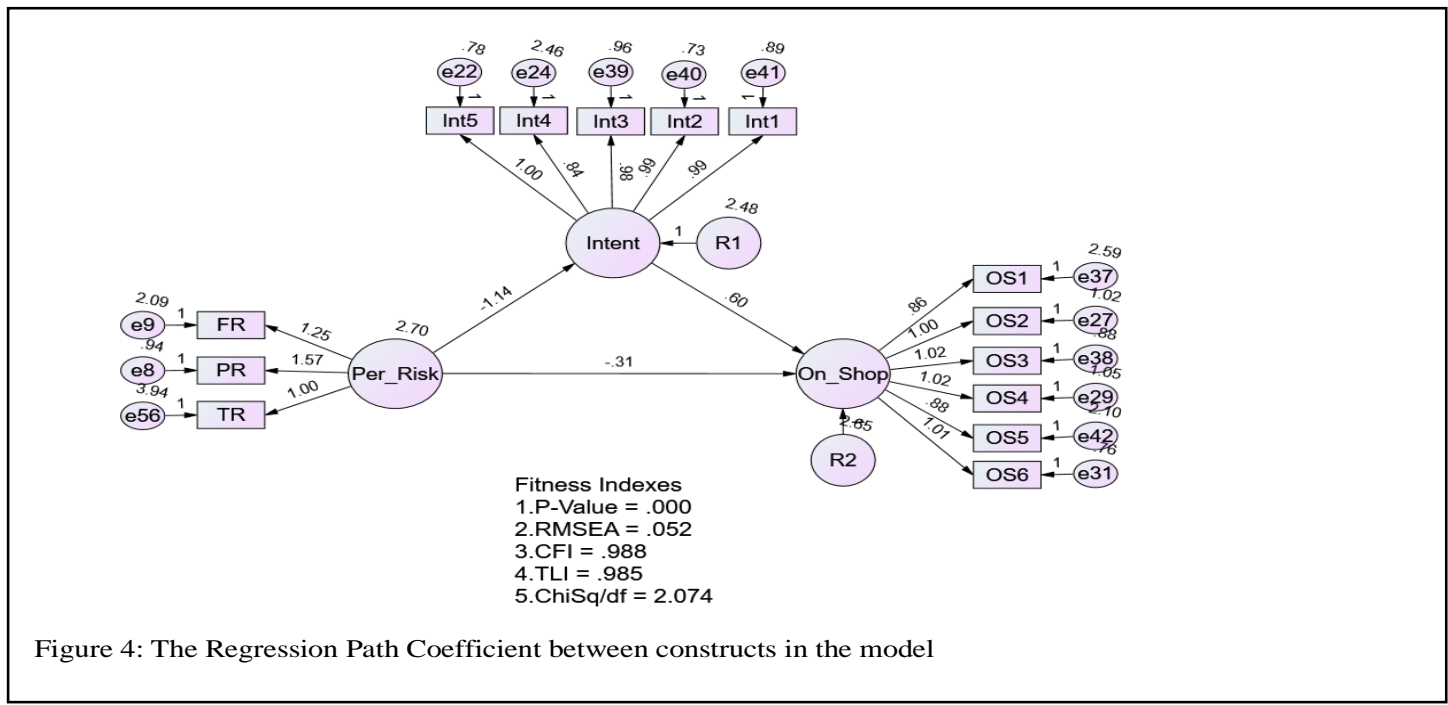

Table 3 present the results of regression path coefficient from the exogenous constructs on the endogenous construct.

Table 3: The Regression Weight and its Significance

\begin{tabular}{|c|c|c|c|c|c|c|c|}
\hline & & & Estimate & S.E. & C.R. & $\mathrm{P}$ & Result \\
\hline Intent & $<---$ & Per_Risk & -.1 .140 & .091 & -12.554 & $* * *$ & significant \\
\hline Onl_Shop & $<--$ & Per_Risk & -.312 & .094 & -3.313 & $* * *$ & significant \\
\hline Onl Shop & $<--$ & Intent & .603 & .062 & 9.718 & $* * *$ & significant \\
\hline
\end{tabular}

Table 4: The Hypothesis Testing for Direct Effect Hypothesis

\begin{tabular}{|l|l|l|}
\hline & Hypothesis Statement & Result \\
\hline H1 & There is a negative relationship between perceived risk and intention. & Supported \\
\hline H2 & $\begin{array}{l}\text { There is a negative relationship between perceived risk and actual } \\
\text { online shopping behavior. }\end{array}$ & Supported \\
\hline H3 & $\begin{array}{l}\text { There is a positive relationship between intention and actual online } \\
\text { shopping behavior. }\end{array}$ & Supported \\
\hline
\end{tabular}

\section{Mediator Testing}

Table 5: The Hypothesis Testing for Mediation Effect of intention

\begin{tabular}{|l|l|}
\hline $\mathrm{H} 4$ & $\begin{array}{l}\text { Intention mediates the relationship between perceived risk } \\
\text { and actual online shopping behavior. }\end{array}$ \\
\hline
\end{tabular}

The study utilized the method suggested by Awang (2015), Awang et al. $(2015,2018)$, and Kashif et al. $(2015,2016)$ for testing the mediation effects in the model. Figure 5 presents the procedure for testing the mediator. The values in Figure 5 are obtained from the output of standardized path coefficients. 


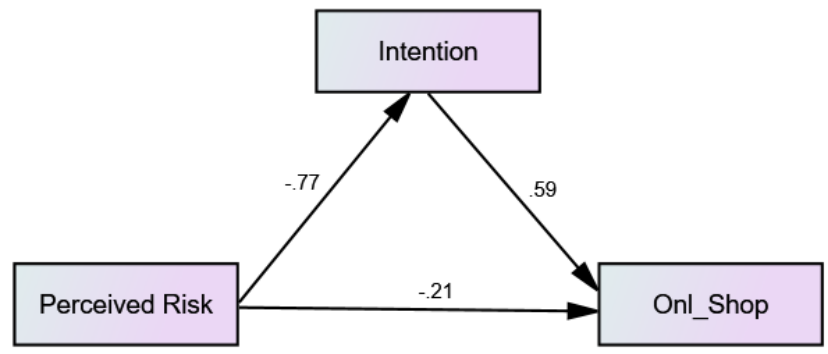

1. The indirect effect $1 \mathrm{a}=-0.77$ (significant)

2. The indirect effect $2 \mathrm{~b}=0.59$ (significant)

3. Total indirect effect $\mathrm{a} * \mathrm{~b}=(-0.77) \cdot(0.59)=-0.020$

4. The direct effect $\mathrm{c}=-0.454$ (significant)

5. Thus, the mediation occurs since both $\mathrm{a}$ and $\mathrm{b}$ are significant

6. The type of mediation is partial mediation since the direct

effect $\mathrm{c}$ is significant.

Figure 5: The mediation testing procedure

\section{Moderator Testing}

In this study, experience was examined as a moderator on the relationship between perceived risk and actual online shopping behavior. With latent constructs, using interaction terms is not practical for standard modeling procedure as it would cause model convergence problems and distortion of standard errors. Ultimately, it creates a misfit model, and the procedure stops (Awang, 2015).

Alternatively, Multi-Group CFA was proposed by (Awang, 2015) as an alternative approach to evaluate the influence of the moderator variable. The researcher needs to define the path of interest where to assess the moderator variable. This specific path will be constrained with parameter $=1$, and the model is called the constrained model. Then, the procedure will estimate two models separately. The first one is the constrained model, and the other one is the unconstrained model. The data were divided into two groups based on their experience level (i.e., low and high level of experience). The moderation is significant if the difference in Chi-Square value between the constrained and unconstrained model is more than 3.84 (Awang, 2015).

Starting with Low experience group, the researcher assigns a constraint parameter to the chosen path of interest equal to "1"as presented in figure 6 . This model is given a new name as the constrained model. Then, using the same model, remove the constraint parameter in the path, as presented in Figure 7. This model is given a new name as the unconstrained model. 


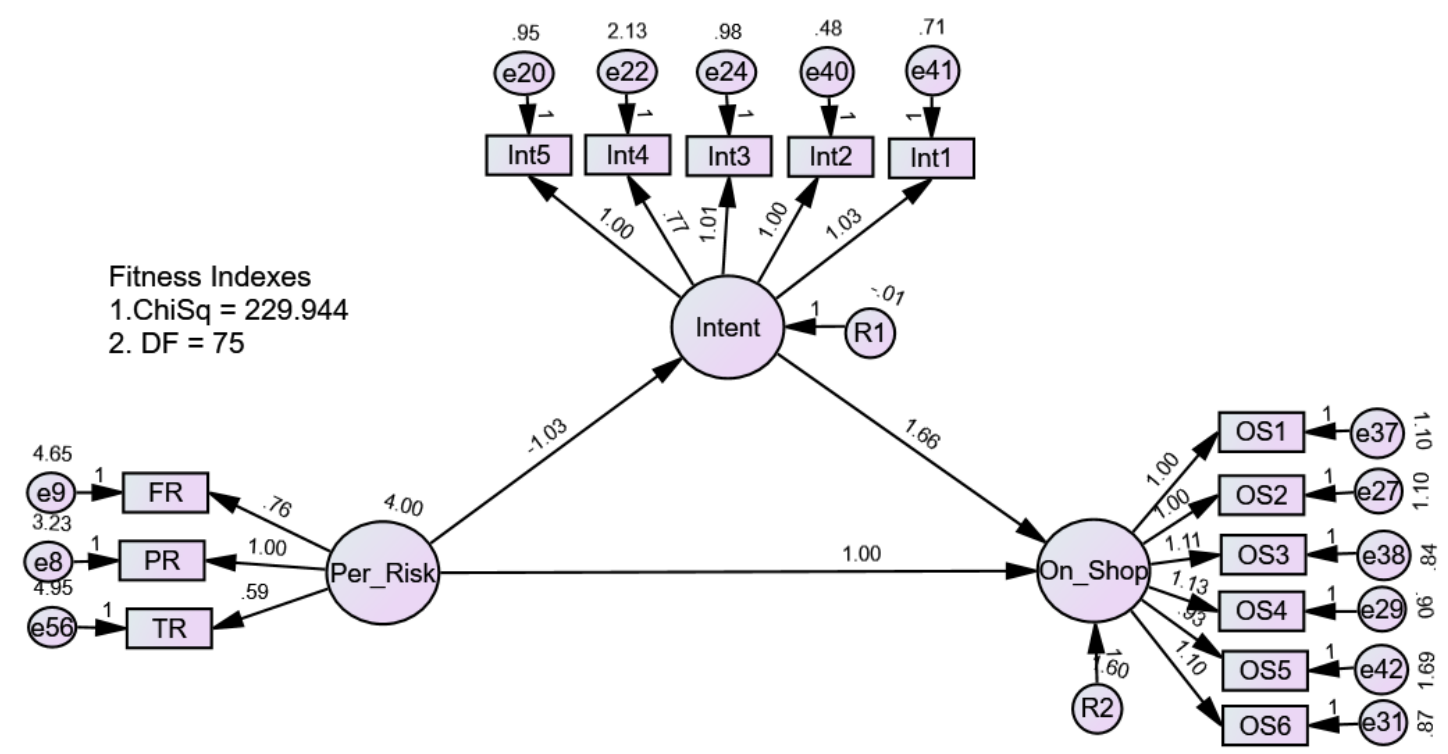

Figure 6: Low Experience and constrained model

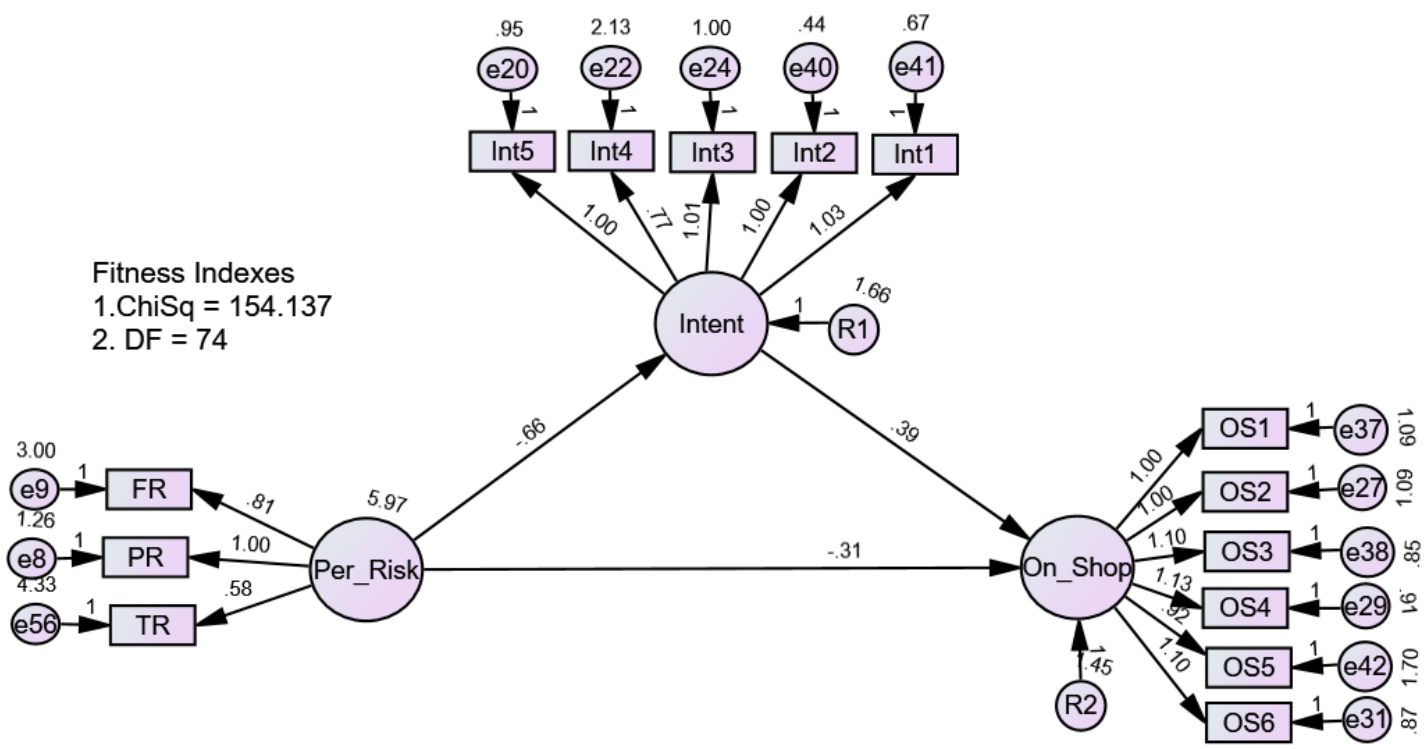

Figure 7: Low Experience and unconstrained model

The same procedure was repeated for the High experience group. Figure 8,9 present the output for the constrained and unconstrained model. 


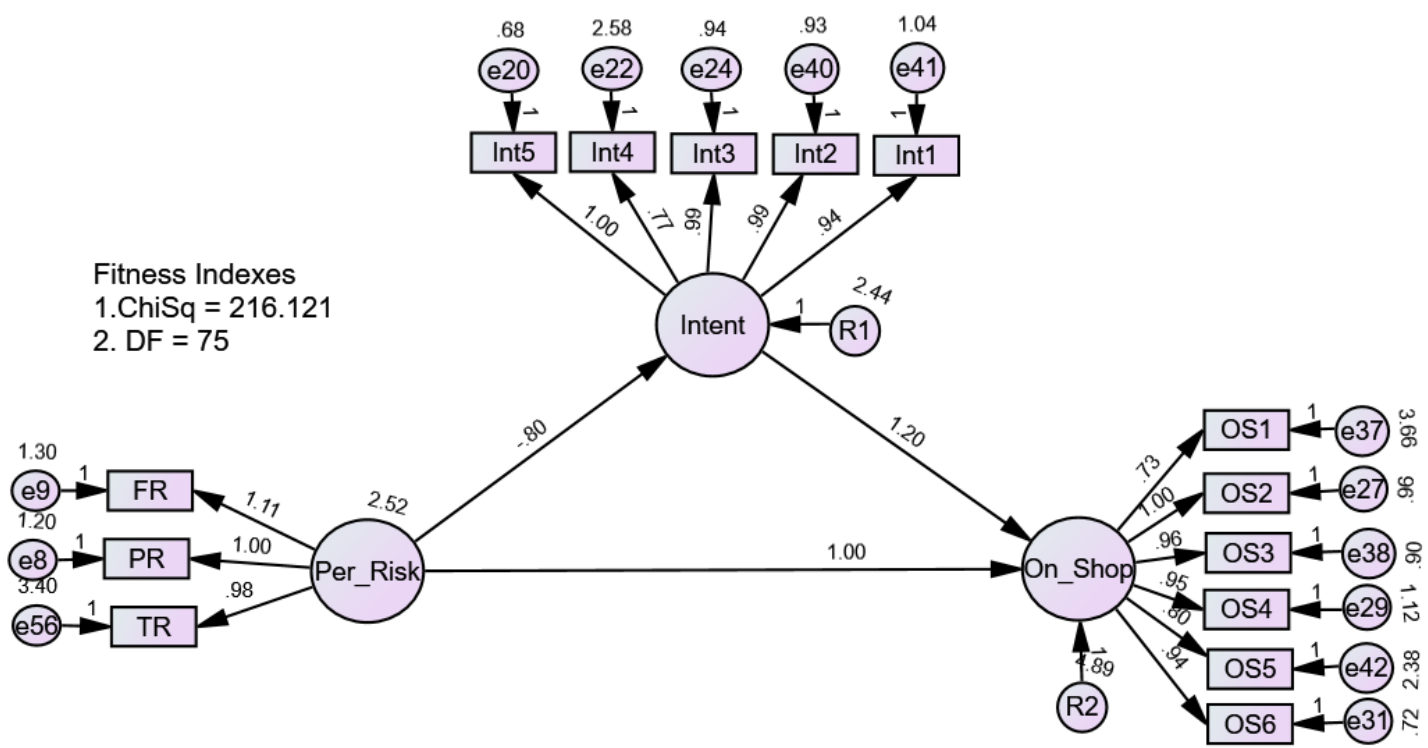

Figure 8: High Experience and constrained model

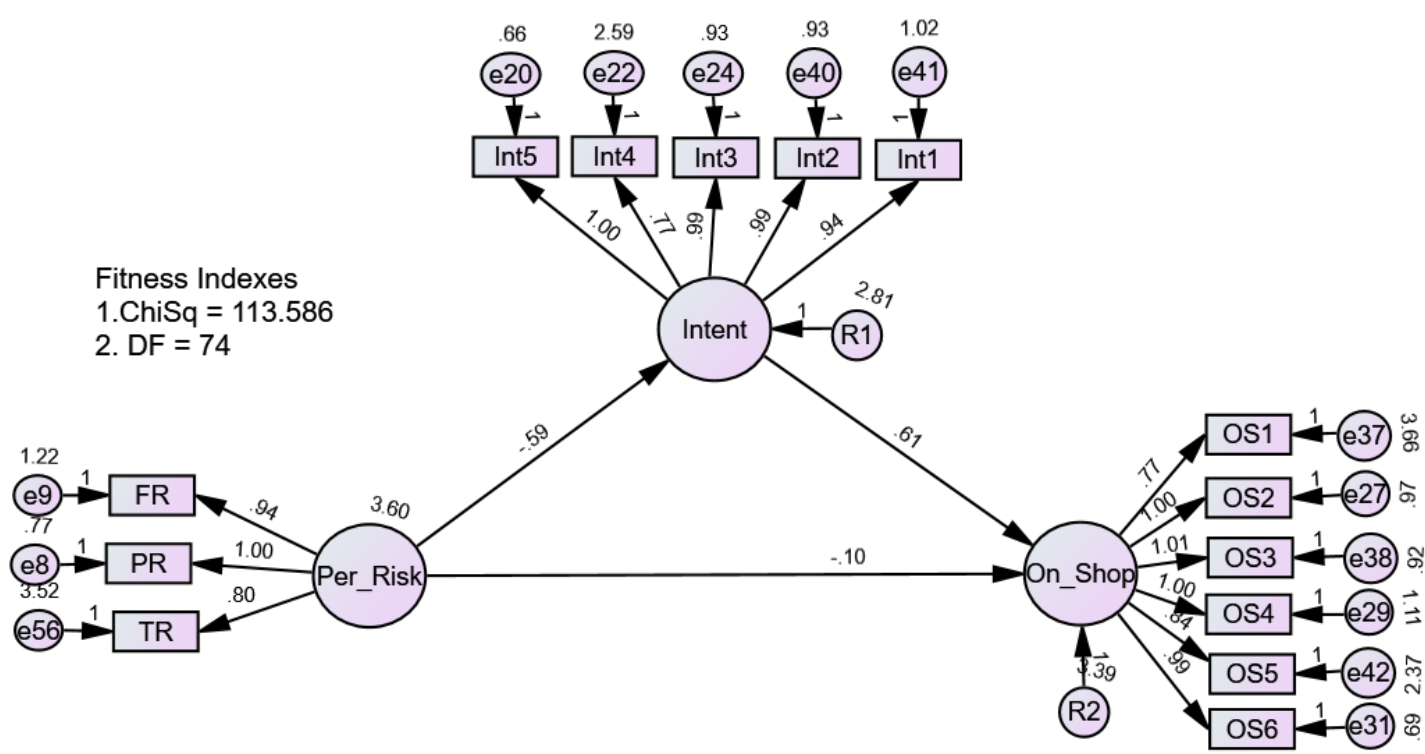

Figure 9: High Experience and unconstrained model

Based on table 6, which shows the results for both groups. We can conclude that there is a significant effect of the moderator experience on the relationship between perceived risk and actual online shopping behavior. Thus hypothesis 5 is supported. 
Table 6: Results Showing the Moderator Effect of experience

\begin{tabular}{|c|c|c|c|c|c|}
\hline $\begin{array}{l}\text { Independen } \\
\text { t Variable }\end{array}$ & $\begin{array}{l}\text { Dependen } \\
\text { t Variable }\end{array}$ & \multicolumn{4}{|c|}{ Moderator Variable } \\
\hline \multirow{5}{*}{$\begin{array}{l}\text { Perceived } \\
\text { Risk }\end{array}$} & \multirow{5}{*}{$\begin{array}{l}\text { Actual } \\
\text { online } \\
\text { shopping } \\
\text { behavior }\end{array}$} & \multicolumn{2}{|c|}{ Low experience } & \multicolumn{2}{|c|}{ High experience } \\
\hline & & $\begin{array}{l}\text { Constrained } \\
\text { Model }\end{array}$ & $\begin{array}{l}\text { Unconstraine } \\
\text { d Model }\end{array}$ & $\begin{array}{l}\text { Constrained } \\
\text { Model }\end{array}$ & $\begin{array}{l}\text { Unconstraine } \\
\text { d Model }\end{array}$ \\
\hline & & 229.944 & 154.137 & 216.121 & 113.586 \\
\hline & & $\begin{array}{l}\text { Chi-Square } \\
75.807\end{array}$ & Difference $=$ & $\begin{array}{l}\text { Chi-Square } \\
102.535\end{array}$ & Difference $=$ \\
\hline & & \multicolumn{2}{|c|}{$\begin{array}{l}\text { Degree of freedom difference } \\
75-74=1\end{array}$} & \multicolumn{2}{|c|}{$\begin{array}{l}\text { Degree of freedom difference } \\
75-74=1\end{array}$} \\
\hline
\end{tabular}

\section{Discussion and Conclusion}

Theoretically, this study has confirmed four essential findings. Firstly, perceived risk has a negative effect on consumers' intention. This result is consistent with several previous studies such as (Zhao et al., 2017) and (Ahmed \& Akhlaq, 2015). Secondly, perceived risk has a negative effect on actual online shopping behavior. This finding is in line with (Zhang et al., 2012). Thirdly, the intention has a positive effect on actual online shopping behavior, which is consistent with (Al-Jabari, 2013; Jamil, 2012). Fourthly, intention showed partial mediation effect in the relationship between perceived risk and actual online shopping behavior.

Therefore, it is recommended that online retailers must promote company focus towards risks associated with online shopping. Moreover, online retailers are required to provide interactive online communication services to handle customer queries, hence, reducing fear to order online.

The finding also revealed that intention partially mediates the relationship between perceived risks and actual online shopping behavior. This finding implies that perceived risks may have an instant effect on online shopping behavior by restricting customers to avoid online shopping. However, perceived risks can develop a negative online purchase intention, which in the future may restrict customers to engage in online shopping.

Moreover, the finding revealed that there is a significant moderating influence of experience on the relationship between perceived risks and actual online shopping behavior. It means that the greater the customers have experience of online shopping, the less of impact of perceived risks on actual online shopping.

Online retailers are suggested to perform the following tasks to reduce the risks and improve the online shopping in Jordan. First, they can provide detailed information about their products and services and security policies. Second, they are suggested to develop confidence in the customers by acknowledging the risks and offering return policy of the unfitting products. Also, online retailers need to set competitive prices in relation to other e-commerce websites. Moreover, e-retailers are required to offer services of guarantee and warranty to reduce the financial risk. Finally, online retailers can reduce the time risk by limiting the time between the order of the product and final delivery. Alongside quick delivery, online retailers must be quick in providing money back for faulty and damaged products.

\section{Theoretical Implication}

This paper explores the contribution of perceived risks to online shopping, thus narrowing the gap in the literature on online shopping behavior regarding perceived risks in Jordan. From a risk perspective, the paper introduces further insights into the perception of consumers' 
online shopping behavior in Jordan. The findings of the study have deepened the knowledge of online retailing in Jordan. Other developing countries can be studied further the model emerged from this research to have an extensive consideration of the factors inducing online purchase.

\section{References}

Afthanorhan, A., Awang, Z., \& Fazella, S. (2017). Developing the patients' loyalty model for medical tourism industry: the case of Malaysia. International Journal of Society Systems Science, 9(2), 139-164.

Afthanorhan, A., Awang, Z., Salleh, F., Ghazali, P., \& Rashid, N. (2018). The effect of product quality, medical price and staff skills on patient loyalty via cultural impact in medical tourism. Management Science Letters, 8(12), 1421-1424.

Afthanorhan, A., Awang, Z., Rashid, N., Foziah, H., \& Ghazali, P. (2019). Assessing the effects of service quality on customer satisfaction. Management Science Letters, 9(1), 13-24.

Ahmed, E., \& Akhlaq, A. (2015). Digital commerce in emerging economies: Factors associated with online shopping intentions in Pakistan. International Journal of Emerging Markets, 10(4), 634-647. https://doi.org/10.1108/IJoEM-01-2014-0051

Ajzen, I. (1991). The theory of planned behavior. Orgnizational Behavior and Human Decision Processes, 50, 179-211. https://doi.org/10.1016/0749-5978(91)90020-T

Al-Jabari. (2013). Factors Influencing Online Shopping Behavior Among Jordanian Academicians Mohammed Abdal Razaq Al-Jabari Universiti Utara Malaysia (Issue June).

Al-Rawad, M. I., Al Khattab, A., Al-Shqairat, Z. I., Krishan, T. A., \& Jarrar, M. H. (2015). An Exploratory Investigation of Consumers' Perceptions of the Risks of Online Shopping in Jordan. International Journal of Marketing Studies, 7(1), 157-166.

https://doi.org/10.5539/ijms.v7n1p157

Ariff, M. S. M., Sylvester, M., Zakuan, N., Ismail, K., \& Ali, K. M. (2014). Consumer perceived risk, attitude and online shopping behaviour; Empirical evidence from Malaysia. IOP Conference Series: Materials Science and Engineering, 58(1). https://doi.org/10.1088/1757-899X/58/1/012007

Awang, Z., Hui, L. S., \& Zainudin, N. F. S. (2018). Pendekatan mudah SEM-Structural equation modelling. Bandar Baru Bangi, MPWS Rich Resources.

Awang, Z. (2012). Research methodology and data analysis second edition. UiTM Press.

Awang, Z. (2015). SEM Made Simple: A Gentle Approach to Learning Structural Equation Modeling, Selangor: MPWS Rich Publication Sdn.

Awang, Z., Afthanorhan, A., Mohamad, M., \& Asri, M. A. M. (2015). An evaluation of measurement model for medical tourism research: the confirmatory factor analysis approach. International Journal of Tourism Policy, 6(1), 29-45.

Aziz, M. I., Afthanorhan, A., \& Awang, Z. (2016). Talent development model for a career in Islamic banking institutions: A SEM approach. Cogent Business \& Management, 3(1), 1186259.

Chen, Y. C., Shang, R. A., \& Kao, C. Y. (2009). The effects of information overload on consumers' subjective state towards buying decision in the internet shopping environment. Electronic Commerce Research and Applications, 8(1), 48-58. https://doi.org/10.1016/j.elerap.2008.09.001

Lorenzo-Romero, C., Constantinides, E., \& Gómez-Borja, M. A. (2013). Web experience effects in a virtual shopping interaction environment. In Consumer information systems and relationship management: design, implementation, and use (pp. 136-155). IGI Global. 
Dai, B., Forsythe, S., \& Kwon, W.-S. (2014). Impact of Online Shopping Experience and Risk Perceptions. Journal of Electronic Commerce Research, 15(1), 13-24.

Featherman, M. S., \& Pavlou, P. A. (2003). Predicting e-services adoption : a perceived risk facets perspective. 59, 451-474. https://doi.org/10.1016/S1071-5819(03)00111-3

Hassan, A. M., Kunz, M. B., Pearson, A. W., \& Mohamed, F. A. (2006). Conceptualization and measurement of perceived risk in online shopping. Marketing Management Journal, 16(1).

Nordin, A. J. (2012). The Integration of Theory of Planned Behaviour (TPB) and Technology Acceptance Model (TAM) in Determining Online Purchasing Behaviour in Malaysia (Doctoral dissertation, Universiti Utara Malaysia).

Kashif, M., Awang, Z., Walsh, J., \& Altaf, U. (2015). I'm loving it but hating US: understanding consumer emotions and perceived service quality of US fast food brands. British Food Journal, 117(9), 2344-2360.

Kashif, M., Braganca, E., Awang, Z., \& De Run, E. C. (2017). You abuse but I will stay: The combined effects of job stress, customer abuse, and emotional intelligence on employee turnover. Journal of Management Development.

Kashif, M., Samsi, S. Z. M., Awang, Z., \& Mohamad, M. (2016). EXQ: measurement of healthcare experience quality in Malaysian settings: A contextualist perspective. International Journal of Pharmaceutical and Healthcare Marketing, 10(1), 27-47.

Kawaf, F., \& Tagg, S. (2017). The construction of online shopping experience: A repertory grid approach. Computers in Human Behavior, 72, 222-232. https://doi.org/10.1016/j.chb.2017.02.055

Ko, H., Jung, J., Kim, J., \& Shim, S. W. (2004). Cross-Cultural Differences in Perceived Risk of Online Shopping. Journal of Interactive Advertising , 4(2), 20-29. https://doi.org/10.1080/15252019.2004.10722084

Laroche, M., Yang, Z., McDougall, G. H. G., \& Bergeron, J. (2005). Internet versus bricks-andmortar retailers: An investigation into intangibility and its consequences. Journal of Retailing, 81(4), 251-267. https://doi.org/10.1016/j.jretai.2004.11.002

Liao, T. H., \& Keng, C. J. (2013). Online shopping delivery delay: Finding a psychological recovery strategy by online consumer experiences. Computers in Human Behavior, 29(4), 1849-1861. https://doi.org/10.1016/j.chb.2013.03.004

Lim, Y. J., Osman, A., Salahuddin, S. N., Romle, A. R., \& Abdullah, S. (2016). Factors Influencing Online Shopping Behavior: The Mediating Role of Purchase Intention. Procedia Economics and Finance, 35(October 2015), 401-410. https://doi.org/10.1016/S22125671(16)00050-2

Mohamad, M., Mohammad, M., Mat Ali, N. A., \& Awang, Z. (2018). The impact of life satisfaction on substance abuse: delinquency as a mediator. International Journal of Adolescence and Youth, 23(1), 25-35.

Mohamad, M., Mohammad, M., Ali, N. A. M., \& Awang, Z. (2016). MEASURING POSITIVE YOUTH DEVELOPMENT: CONFIRMATORY FACTOR ANALYSIS.

Mohamad, M., Awang, Z., \& Ali, N. A. M. (2017). Validating the maqasid shariah prison quality of Life (MSPQoL) among drug-abuse inmates using confirmatory factor analysis. International Journal of Applied Business and Economic Research, 15(24), 91103.

Noor, N. M., Aziz, A. A., Mostapa, M. R., \& Awang, Z. (2015). Validation of the Malay version of the Inventory of Functional Status after Childbirth questionnaire. BioMed research international, 2015. 
Pappas, I. O., Pateli, A. G., Giannakos, M. N., \& Chrissikopoulos, V. (2014). Moderating effects of online shopping experience on customer satisfaction and repurchase intentions. International Journal of Retail \& Distribution Management.

Orubu, O. F. (2016). The impact of perceived risk on willingness to buy in online markets. E3 Journal of Business Management and Economics, 7(1), 013-018. https://doi.org/10.18685/ejbme(7)1_ejbme-15-020

Rizwan, M., Umair, S. M., Bilal, H. M., Akhtar, M., \& Bhatti, M. S. (2014). Determinants of customer intentions for online shopping: A Study from Pakistan. Journal of Sociological Research, 5(1). https://doi.org/10.5296/jsr.v5i1.6565

Schierz, P. G., Schilke, O., \& Wirtz, B. W. (2010). Understanding consumer acceptance of mobile payment services: An empirical analysis. Electronic Commerce Research and Applications, 9(3), 209-216. https://doi.org/10.1016/j.elerap.2009.07.005

Wen, T. S., Satar, N. M., Ishak, N. A., \& Ating, R. (2020). CONSUMER INTENTION TOWARDS ONLINE SHOPPING IN MALAYSIA. International Journal of Accounting, 5(27), 93-117.

Wai, K., Dastane, O., Johari, Z., \& Ismail, N. B. (2019). Perceived risk factors affecting consumers' online shopping behaviour. The Journal of Asian Finance, Economics and Business, 6(4), 246-260.

Yusof, Y., Awang, Z., Jusoff, K., \& Ibrahim, Y. (2017). The influence of green practices by nongreen hotels on customer satisfaction and loyalty in hotel and tourism industry. International Journal of Green Economics, 11(1), 1-14.

Yusof, Y., Ibrahim, Y., \& Awang, Z. (2018). Awareness of Environmental Issues Among Consumers in the Malaysian Hotel Industry. In Driving Green Consumerism Through Strategic Sustainability Marketing (pp. 1-22). IGI Global.

Zhang, L., Tan, W., Xu, Y., \& Tan, G. (2012). Dimensions of Consumers' Perceived Risk and Their Influences on Online Consumers' Purchasing Behavior. Communications in Information Science and Management Engineering, 2(7), 8-14. https://doi.org/10.1007/978-3-642-24823-8_1

Zhao, X., Deng, S., \& Zhou, Y. (2017). The impact of reference effects on online purchase intention of agricultural products: The moderating role of consumers' food safety consciousness. Internet Research, 27(2), 233-255. https://doi.org/10.1108/IntR-032016-0082

Zheng, L., Favier, M., Huang, P., \& Coat, F. (2012). Chinese consumer perceived risk and risk relievers in e-shopping. 17th Symposium of the Association Information and Management 2012, AIM 2012, 13(3), 255-274. 